\title{
KRAS NP_004976.2:p.Q61R
}

National Cancer Institute

\section{Source}

National Cancer Institute. KRAS NP 004976.2:p.Q61R. NCI Thesaurus. Code C98437.

A change in the amino acid residue at position 61 in the GTPase KRas protein where glutamine has been replaced by arginine. 